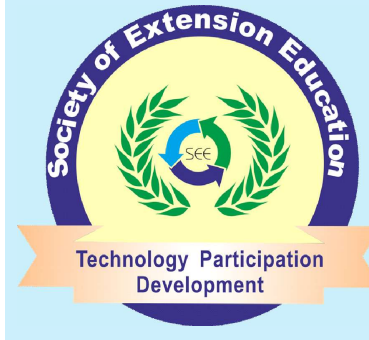

Research Note

\section{Indian Research Journal of Extension Education}

ISSN: 0972-2181 (Print), 0976-1071 (Online)

NAAS Rating : 5.22

Journal homepage: seea.org.in

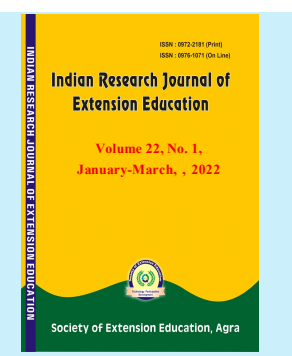

https://doi.org/10.54986/irjee/2022/jan_mar/151-154

\title{
Effect of Nitrogen and Phosphorus Fertilization on the Growth and Yield of Mustard Under Irrigated Conditions in Agra District
}

\author{
Avinash Singh ${ }^{1}$, S.P. Maurya ${ }^{2}$, Vikram Singh ${ }^{3}$ \\ 1\&2. Ex.PG Scholar, 2. Asstt. Prof., Department of Agronomy, R.B.S College, Bichpuri, Agra. \\ Corresponding author e-mail : avinashjadon9@gmail.com
}

Paper Received on September 11, 2021, Accepted on Novembe 24, 2021 and Published Online on January 01,2022

\begin{abstract}
The present field experiment was conducted at Agricultural Research Farm of RBS College, Bichpuri Agra, during Rabi season of 2018-19. The soil of the experimental site is Gangetic alluvial. The experimental was laid out in RBD factorial having 3 main treatment ( $N$ level) and 4 sub treatments $\left(\mathrm{P}_{2} \mathrm{O}_{5}\right.$ level) with 3 replications. All growth and yield attributing character increase with application of $N @ 120 \mathrm{Kg}^{-1}$ and $\mathrm{P}_{2} \mathrm{O}_{5} @ 60 \mathrm{~kg}^{-1}$. All the yield components i.e., number of siliquae plant ${ }^{-1}$, length of siliqua and number of seeds siliqua ${ }^{-1}$ improved with the increase in the level of nitrogen. Higher value of harvest index was associated with the application of $60 \mathrm{~kg} P_{2} \mathrm{O}_{5} \mathrm{ha}^{-1}$. Seed yield increased appreciably with every additional increase in the level of nitrogen. Respectively 26.85 and 40.05 per cent

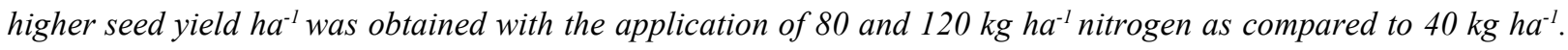

Key words: Rapeseed/Mustard; NWPZ; Harvest index; Sustainable; Yield; Cropping.

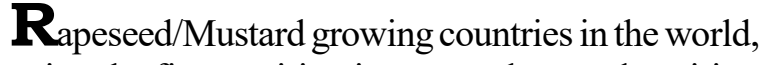
occupying the first position in area and second position in production after China. The world production of rapeseed/mustard has been increasing at a rapid rate in several countries largely in response to the continuing increase in demand for edible oils and its products. Rapeseed/mustard crops in India are grown in diverse agro climatic conditions ranging from North-Eastern / North -Western hills to down south under irrigated/ rainfed, timely/late sown, saline soils and mixed cropping. The nutrient requirement of oilseed crops, in general, is very high for almost all the essential mineral nutrients which are to be supplied in adequate quantities ( $\mathrm{Jat}$, et al., 2017). The most important role of $\mathrm{N}$ in the plant is its presence in the structure of protein, the most important building substances from which the living material or protoplasm of every cell is made. In addition, nitrogen is also found in chlorophyll, the green colouring matter of leaves. Chlorophyll enables the plant to transfer energy from sunlight by photosynthesis. Therefore, the nitrogen supply to the plant will influence the amount of protein, protoplasm and chlorophyll formed. In turn, this influences cell size and leaf area, and photosynthetic activity (Bhat, et al., 2006). Mustard is very sensitive to insufficient nitrogen and very responsive to nitrogen fertilization. The production of mustard is not being fully exploited because of the lack of proper information of nutritional and water requirement. The important constraints to crop growth are those caused by shortage of plant nutrients. The nutrient requirement of oilseed crops, in general, is very high for almost all the essential mineral nutrients which are to be supplied in adequate quantities Plants need phosphorus for growth, utilization of sugar and starch, 
photosynthesis, nucleus formation and cell division. Phosphorus compounds are involved in the transfer and storage of energy within plants. To optimize crop nutrition, phosphorus must be available to the crop in adequate amounts during the growing season. Plants need phosphorus throughout their life cycle, especially during early growth stages for cell division and during maturity stage for seed formation and increase in seed weight. Phosphorus is mobile in the plant, so it is absorbed during early growth and is later Introduction 7 redirected for use in seed formation. Higher phosphorus levels increased the yield and $\mathrm{N}$ use efficiency (Yaping, et al. 2015).

\section{METHODOLOGY}

The present field experiment was conducted at Agricultural Research Farm of RBS College, Bichpuri Agra, during Rabi season of 2018-19. The soil of the experimental site is Gangetic alluvial in origin with calcareous layer at the depth of about 1.5-2.0 meters and is well drained. The soil has ph 7.84, organic carbon $0.34 \%$ available $\mathrm{N} 174.40 \mathrm{Kg} \mathrm{ha}^{-1}, \mathrm{P}_{2} \mathrm{O}_{5} 25.80 \mathrm{Kg} \mathrm{ha}^{-1}$, $\mathrm{K}_{2} \mathrm{O} 220.70 \% \mathrm{Kg} \mathrm{ha}^{-1}$. The experimental was laidout in RBD factorial having 3 main treatment and 4 sub treatments with 3 replications as given below.

\begin{tabular}{cc}
\hline Nitrogen levels, $\left(\mathrm{kg} \mathrm{ha}^{-1}\right)$ & Phosphorus levels, $\left(\mathrm{kg} \mathrm{ha}^{-1}\right)$ \\
\hline $40: \mathrm{N}_{1}$ & $0: \mathrm{P}_{0}$ \\
$80: \mathrm{N}_{2}$ & $20: \mathrm{P}_{1}$ \\
$120: \mathrm{N}_{3}$ & $40: \mathrm{P}_{2}$ \\
- & $60: \mathrm{P}_{3}$
\end{tabular}

Pre-sowing irrigation applied for good initial moisture level in soil for better germination. The quality seed of variety was sown @ $5 \mathrm{~kg} \mathrm{ha}^{-1}$ at the row-to-row distance of $45 \mathrm{~cm}$. Full amount of nitrogen and $\mathrm{P}_{2} \mathrm{O}_{5}$ as per treatment through urea $(46 \% \mathrm{~N})$ and $\operatorname{SSP}\left(16 \% \mathrm{P}_{2} 0_{5}\right)$ along with $30 \mathrm{~kg} \mathrm{~K}_{2} \mathrm{O} \mathrm{ha}^{-1}$ through $\mathrm{MOP}\left(60 \% \mathrm{~K}_{2} \mathrm{O}\right)$ were applied at the time of sowing as basal dressing.

\section{RESULTS AND DISCUSSION}

Progressive data in Table 1.0 on growth characters of Indian mustard in terms of plant stand, plant height, number of primary and secondary branches plant ${ }^{-1}$, number of green leaves plant ${ }^{-1}$ and dry matter accumulation and the main yield attributing characters are number of siliquae plant ${ }^{-1}$, length of siliquae, number of seeds siliquae ${ }^{-1}$ and 1000 seed weight. maximum crop stands metre ${ }^{-1}$ row length was recorded with $120 \mathrm{~kg} \mathrm{~N}$ $\mathrm{ha}^{-1}$ and application of $60 \mathrm{~kg} \mathrm{P}_{2} \mathrm{O}_{5} \mathrm{ha}^{-1}$ showed maximum crop stand. At harvest, the increase in plant height with the application of $120 \mathrm{~kg} \mathrm{~N} \mathrm{ha}^{-1}$ was to the tune of 2.89 and $18.03 \%$. At harvest, the increase in plant height with the application of $60 \mathrm{~kg} \mathrm{P}_{2} \mathrm{O}_{5}$ ha $^{-1}$ was to the tune of $3.00,5.10$ and $8.34 \%$. The number of green leaves plant $^{-1}$ increased significantly with the application of 120 $\mathrm{kg} \mathrm{N} \mathrm{ha}^{-1}$ At $90 \mathrm{DAS}$, the magnitude of increase in number of green leaves plant ${ }^{-1}$ with the $60 \mathrm{~kg} \mathrm{P}_{2} \mathrm{O}_{5}$ ha $^{-1}$. At harvest the magnitude of increase in number of primary branches with $120 \mathrm{~kg} \mathrm{~N} \mathrm{ha}^{-1}$. At harvest, the increase in number of primary branches plant ${ }^{-1} 60 \mathrm{~kg}$ $\mathrm{P}_{2} \mathrm{O}_{5} \mathrm{ha}^{-1}$ was to the tune of 15.87 and $19.76 \%$. At harvest experimental findings the increase in secondary branches plant ${ }^{-1}$ was to the tune 024.75 per cent, respectively with the application of $120 \mathrm{ha}^{-1}$. At harvest,

Table 1. Growth and Yield contributing characters of mustard as influenced by various treatments

\begin{tabular}{|c|c|c|c|c|c|c|c|c|c|c|c|}
\hline Tre & & 1 & 2 & 3 & 4 & 5 & 6 & 7 & 8 & 9 & 10 \\
\hline \multicolumn{12}{|c|}{ Nitrogen level $\left(\mathrm{kg} \mathrm{ha^{-1 } )}\right.$} \\
\hline 40 & N1 & 9.80 & 148.64 & 3.14 & 4.84 & 13.21 & 39.25 & 175.73 & 4.85 & 11.41 & 4.44 \\
\hline 80 & $\mathrm{~N} 2$ & 9.85 & 170.52 & 4.44 & 5.62 & 15.04 & 55.23 & 189.15 & 5.14 & 12.36 & 5.06 \\
\hline 120 & N3 & 10.17 & 175.44 & 4.65 & 6.28 & 16.48 & 58.50 & 208.50 & 5.36 & 13.04 & 5.62 \\
\hline SEn & & 0.20 & 1.18 & 0.26 & 0.213 & 0.472 & 1.030 & 4.01 & 0.070 & 0.210 & 0.140 \\
\hline $\mathrm{CD}$ & & NS & 3.46 & 0.76 & 0.62 & 1.38 & 3.02 & 11.75 & 0.21 & 0.62 & 0.41 \\
\hline \multicolumn{12}{|c|}{ Phosphorus level $\left(\mathrm{kg} \mathrm{ha}^{-1}\right)$} \\
\hline 0 & $\mathrm{P} 0$ & 9.58 & 158.30 & 3.57 & 5.06 & 13.38 & 43.10 & 172.90 & 4.72 & 11.38 & 4.42 \\
\hline 20 & P 1 & 9.82 & 163.17 & 3.65 & 5.23 & 13.94 & 46.40 & 185.13 & 5.00 & 11.98 & 4.82 \\
\hline 40 & P 2 & 10.04 & 166.51 & 4.35 & 5.97 & 16.02 & 55.78 & 198.12 & 5.28 & 12.54 & 5.28 \\
\hline 60 & P 3 & 10.30 & 171.50 & 4.74 & 6.06 & 16.30 & 58.68 & 208.38 & 5.48 & 13.17 & 5.65 \\
\hline SEn & & 0.17 & 1.02 & 0.22 & 0.184 & 0.409 & 0.892 & 3.47 & 0.061 & 0.182 & 0.121 \\
\hline $\mathrm{CD}$ & & NS & 2.99 & 0.65 & 0.54 & 1.20 & 2.61 & 10.18 & 0.18 & 0.53 & 0.36 \\
\hline
\end{tabular}

$1=$ Crop stand, $2=$ Plant height, $3=$ No. of green leaves plant ${ }^{-1}, 4=$ No. of primary branch plant ${ }^{-1}, 5=$ No. of secondary branch plant ${ }^{-1}$,

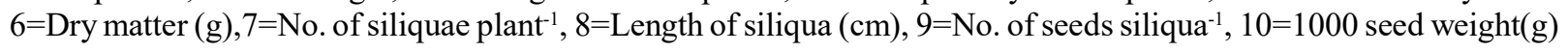


Table 2. Biological Yield, seed and stalk yield of mustard as influenced by various treatments

\begin{tabular}{|c|c|c|c|c|c|}
\hline Treatments & & $\begin{array}{l}\text { Biological } \\
\text { yield }\left(\mathrm{qha}^{-1}\right)\end{array}$ & $\begin{array}{l}\text { Seed } \\
\left(\mathrm{qha}^{-1}\right)\end{array}$ & $\begin{array}{c}\text { Stalk } \\
\left(\text { qha }^{-1}\right)\end{array}$ & $\begin{array}{l}\text { Harvest } \\
\text { index }(\%)\end{array}$ \\
\hline \multicolumn{6}{|c|}{ Nitrogen level $\left(\mathrm{kg} \mathrm{ha}^{-1}\right)$} \\
\hline 40 & N1 & 40.24 & 11.21 & 29.03 & 27.86 \\
\hline 80 & $\mathrm{~N} 2$ & 47.48 & 14.22 & 33.26 & 29.95 \\
\hline 120 & $\mathrm{~N} 3$ & 50.54 & 15.70 & 34.84 & 31.06 \\
\hline $\mathrm{SEm}+$ & & 1.02 & 0.42 & 0.48 & 0.98 \\
\hline CD at $5 \%$ & & 2.99 & 1.23 & $1.41^{\mathrm{NS}}$ & \\
\hline \multicolumn{6}{|c|}{ Phosphorus level $\left(\mathrm{kg} \mathrm{ha}^{-1}\right)$} \\
\hline 0 & $\mathrm{P} 0$ & 40.06 & 11.28 & 28.78 & 28.16 \\
\hline 20 & P 1 & 45.03 & 13.05 & 31.98 & 28.98 \\
\hline 40 & P 2 & 48.30 & 14.48 & 33.82 & 29.98 \\
\hline 60 & P 3 & 50.97 & 15.63 & 35.34 & 30.67 \\
\hline $\mathrm{SEm} \pm$ & & 0.88 & 0.364 & 0.416 & 0.849 \\
\hline $\mathrm{CD}$ at $5 \%$ & & 2.59 & 1.07 & $1.22^{\mathrm{NS}}$ & \\
\hline
\end{tabular}

Table 3. Economics of mustard crop $\left(\mathrm{Rs} \mathrm{ha}^{-1}\right)$ as influenced by levels of nitrogen and phosphorus.

\begin{tabular}{llllll}
\hline Treatments & GI & CC & CoC & NI & BCR \\
\hline $\mathrm{N}_{1} \mathrm{P}_{0}$ & 53010 & 19450 & 20015 & 32995 & 2.65 \\
$\mathrm{~N}_{1} \mathrm{P}_{1}$ & 57047 & 19450 & 21065 & 35982 & 2.71 \\
$\mathrm{~N}_{1} \mathrm{P}_{2}$ & 60234 & 19450 & 22115 & 38119 & 2.72 \\
$\mathrm{~N}_{1} \mathrm{P}_{3}$ & 62801 & 19450 & 23165 & 39636 & 2.71 \\
$\mathrm{~N}_{2} \mathrm{P}_{0}$ & 59754 & 19450 & 20580 & 39174 & 2.90 \\
$\mathrm{~N}_{2} \mathrm{P}_{1}$ & 63791 & 19450 & 21630 & 42161 & 2.95 \\
$\mathrm{~N}_{2} \mathrm{P}_{2}$ & 66978 & 19450 & 22680 & 44298 & 2.95 \\
$\mathrm{~N}_{2} \mathrm{P}_{3}$ & 69545 & 19450 & 23730 & 45815 & 2.93 \\
$\mathrm{~N}_{3} \mathrm{P}_{0}$ & 63020 & 19450 & 21146 & 41874 & 2.98 \\
$\mathrm{~N}_{3} \mathrm{P}_{1}$ & 67057 & 19450 & 22196 & 44861 & 3.02 \\
$\mathrm{~N}_{3} \mathrm{P}_{2}$ & 70244 & 19450 & 23246 & 46998 & 3.02 \\
$\mathrm{~N}_{3} \mathrm{P}_{3}$ & 72811 & 19450 & 24296 & 48515 & 3.00 \\
\hline
\end{tabular}

GI $=$ Gross income $\left(\right.$ Rs ha $\left.^{-1}\right), \mathrm{CC}=$ Common $\operatorname{cost}\left(\mathrm{Rs} \mathrm{ha}^{-1}\right)$

$\mathrm{CoC}=$ Cost of cultivation $\left(\mathrm{Rs} \mathrm{ha}^{-1}\right), \mathrm{NI}=$ Net-income $\left(\mathrm{Rs} \mathrm{ha}^{-1}\right)$ $\mathrm{BCR}=\mathrm{B}: \mathrm{C}$ Ratio

and $60 \mathrm{~kg} \mathrm{P}_{2} \mathrm{O}_{5}$ ha $^{-1}$ was to the tune of 16.93 and 21.82 per cent. At harvest the increase in dry matter accumulation in plant with the application $120 \mathrm{~kg} \mathrm{~N}^{-}$ ${ }^{1}$ was to the tune of dry matter accumulation in plant was to the tune 49.04 per cent. At harvest, the magnitude of increase in dry matter accumulation in plant with the $60 \mathrm{~kg} \mathrm{P}_{2} \mathrm{O}_{5}$ ha $^{-1}$ was to the tune of 36.15 per cent. Application of nitrogen@120 kg N ha-1 increased siliquae plant ${ }^{-1} 18.65$ per cent than that of $40 \mathrm{~kg} \mathrm{~N} \mathrm{ha}^{-1}$. increase in the level of phosphorus significantly increase number of siliquae plant ${ }^{-1}$ upto $60 \mathrm{~kg} \mathrm{P}_{2} \mathrm{O}_{5} \mathrm{ha}^{-1} 20.52 \%$. Length of siliqua increased appreciably with increase in level of nitrogen up to $120 \mathrm{~kg} \mathrm{~N} \mathrm{ha}^{-1}$. Effect of
Phosphorus Every increase in the level of phosphorus increased length of siliqua significantly up to $60 \mathrm{~kg} \mathrm{P}_{2} \mathrm{O}_{5}$ ha $^{-1} 16.10 \%$ (Mishra, et al., 2010). Effect of Nitrogen Every increasing level of nitrogen application increased number of seeds siliqua ${ }^{-1}$ significantly and the variation in number of seeds siliqua ${ }^{-1}$ with the application of 120 $\mathrm{kg} \mathrm{N} \mathrm{ha}^{-1}$ and 14.28 per cent. Effect of Phosphorus the number of seeds siliqua- ${ }^{1}$ with the application of $\mathrm{kg} \mathrm{P}_{2} \mathrm{O}_{5}$ $\mathrm{ha}^{-1}$ was to the tune 15.73 per cent over control (no phosphorus). Effect of Nitrogen The examination of data concluded that the 1000 -seed weight increased significantly with every increase in levels of nitrogen up to $120 \mathrm{~kg} \mathrm{~N} \mathrm{ha}^{-1}(\mathrm{~N} 3)$ which registered 11.07 and 26.58 per cent higher 1000- seed. All the yield components i.e., number of siliquae plant ${ }^{-1}$, length of siliqua and number of seeds siliqua ${ }^{-1}$ improved with the increase in the level of nitrogen. These yields contributing characters influenced the seed yield plant ${ }^{-1}$, which, in turn, was responsible for higher seed yield per hectare with increasing levels of nitrogen. Similar results were obtained by Rajput, R.K. (2017). The plant growth Discussion 55 attributes such as plant height, number of green leaves per plant, number of primary and secondary branches plant ${ }^{-1}$ also appreciably improved with the application of phosphorus upto $60 \mathrm{~kg} \mathrm{P}_{2} \mathrm{O}_{5}$ ha' $^{-1}$.

Yield: Table 2 shows that the yield of any crop is generally based on two major factors, yield plant ${ }^{-1}$ and plant population unit- 1 area. Further the yield plant ${ }^{-1}$ is affected by several characters namely number of siliquae plant ${ }^{-1}$, length of siliquae, number of seeds siliqua1 and 1000 seed weight. Reference to shows that total biological yield qha ${ }^{-1}$ appreciably increased with every increase in the level of phosphorus application up-to 60 $\mathrm{kg} \mathrm{P}_{2} \mathrm{O}_{5} \mathrm{ha}^{-1}$. The increase in biological yield with 20 , 40 and $60 \mathrm{~kg} \mathrm{P}_{2} \mathrm{O}_{5}$ ha-1 significantly Biological yield ha${ }^{1}$ by 17.99 and 25.60 per cent was obtained with the application of 80 and $120 \mathrm{~kg} \mathrm{~N}^{-1}$ when compared with $40 \mathrm{~kg} \mathrm{~N} \mathrm{ha}^{-1}$, respectively. Application of 20, 40 and $60 \mathrm{~kg} \mathrm{P}_{2} \mathrm{O}_{5}$ ha $^{-1}$ significantly produced $12.41,20.57$ and 27.23 per cent higher biological yield than that of recorded with control, respectively. Effect of Nitrogen The application of various nitrogen levels influenced seed yield significantly. Seed yield increased appreciably with every additional increase in the level of nitrogen. Respectively 26.85 and 40.05 per cent higher seed yield $\mathrm{ha}^{-1}$ was obtained with the application of 80 and $120 \mathrm{~kg}$ $\mathrm{ha}^{-1}$ nitrogen as compared to $40 \mathrm{~kg} \mathrm{ha}^{-1}$ increase in seed 
yield ha ${ }^{-1}$ with the application of 20,40 and $60 \mathrm{~kg} \mathrm{P}_{2} \mathrm{O}_{5}$ $\mathrm{ha}^{-1}$ was to the tune of $15.69,28.37$ and 38.56 per cent over control, respectively Singh, et al. (2010).

Table 3 reveals that nitrogen levels nitrogen levels had no appreciable effect on harvest index. However, the maximum harvest index was recorded with the

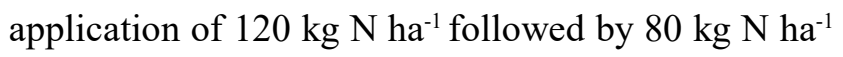
Different levels of phosphorus levels had no significant effect on harvest index, however, the highest harvest index $(30.67 \%)$ was recorded with the application of $60 \mathrm{~kg} \mathrm{P}_{2} \mathrm{O}_{5} \mathrm{ha}^{-1}$. Harvest index did not modify significantly due to application of different levels of phosphorus. However, higher value of harvest index and
Economics of the crop was associated with the application of $60 \mathrm{~kg} \mathrm{P}_{2} \mathrm{O}_{5}$ ha $^{-1}$ Panotra, et al. (2016).

\section{CONCLUSION}

The present study could be concluded that the seed yield of mustard (Brassica juncea L.) can be increased significantly under the agro-climatic condition of Agra region in U.P. with the application of $120 \mathrm{Kg} \mathrm{N} \mathrm{ha}^{1}$ and $60 \mathrm{Kg} \mathrm{P}_{2} \mathrm{O}_{5}$ ha $^{-1}$. The highest B:C ratio obtained with the application of $120 \mathrm{~kg} \mathrm{~N} \mathrm{ha}^{-1}$ and $60 \mathrm{Kg} \mathrm{P}_{2} \mathrm{O}_{5} \mathrm{ha}^{-1}$.

\section{CONFLICTS OF INTEREST}

The authors declare that they have no conflicts of interest.

\section{REFERENCES}

Bhat, S. A.; Khan, F. A. and Khan, M. I. (2006). Effect of nitrogen and phosphorus on growth, nutrient content, seed yield and quality of mustard. Indian $\mathrm{JPl}$., 11:281-86

Jat, A.L.; Prajapati, K.P.; Patel, B.K.; Patel, P.J.; Patel, J.R.; Shah, S.K. and Desai, A.G. (2017). Influence of NPK Levels on Performance of Indian Mustard (Brassica juncea L.), Intl. J. Cur. Micro. and App.Sci., 6 (9) : 1986-1990.

Mishra, S.V.; Maurya, D. and Gupta. G. (2010). Effect of phosphorus and sulphur and their interaction on mustard crop, Asian Sci., 5 (2) : 79-84.

Panotra, N.; Kumar, A. and Singh, O.P. (2016). Impact of Different Levels of Fertilizer on Growth and Yield of Indian Mustard (Brassica juncea) under Irrigated Condition of Western U.P., International Journal of Science and Nature,7 (4): $802-804$.

Rajput, R.K. (2017) Effect of Nitrogen and Sulphur levels on nutrients uptake and yield of Indian mustard (Brassica juncea VI L. Czern \& Coss.) International Archive of Applied Sciences and Technology, 8 (3) : 29-31

Singh, Y.; Singh, T.; Singh, U.N. and Rajput, P.K. (2010). Effect of nutrient management on yield, quality and economics of irrigated Indian mustard (Brassica juncea). Indian J. Agric. Sci., 80 : 691-94.

Yaping, Xie; Xiaoxia, Niu and Junyi, Niu (2015). Effect of phosphorus fertilizer on growth, phosphorus uptake, seed yield, yield components, and phosphorus use efficiency of oilseed flax, American Journal of Agronomy, 108 (3):1257-1266. 